\title{
KAJIAN POLA INTERAKSI LAND USE DENGAN VOLUME PENUMPANG BSD LINK KORIDOR SEKTOR 1.3 - GREENWICH PARK
}

\author{
Verdy Ananda Upa ${ }^{1)}$, Rahmat Setyadi' ${ }^{2}$ \\ 1, 2) Program Studi Teknik Sipil, Institut Teknologi Indonesia \\ Jl. Raya Puspiptek Serpong, Kota Tangerang Selatan \\ Email: verdy.ananda@iti.ac.id ${ }^{1)}$, rs.rahmat $@ i t i . a c . i d^{21}$
}

DOI: http://dx.doi.org/10.29103/tj.v11i2.581

(Received: July 2021 / Revised: August 2021 / Accepted: September 2021)

\begin{abstract}
Abstrak
Bumi Serpong Damai (BSD) merupakan salah satu kota mandiri di kawasan Jabodetabek. Sinarmas Land sebagai developer kawasan BSD telah memulai untuk membangun Angkutan Massal Cepat yang dioperasikan khusus di kawasan tersebut. Konsep Angkutan Massal yang dipilih berupa Bus Rapid Transit (BRT). Jumlah halte bus BSD Link untuk satu koridor dengan dua arah tidak persis sama, karena rute untuk keberangkatan dan kembalinya berbeda. Hal itu disebabkan karena perbedaan karakteristik dari pola tata guna lahan dari rute BSD Link tersebut. Oleh sebab itu, interaksi antara pola tata guna lahan dengan fluktuasi volume penumpang BSD Link setiap halte perlu diketahui. Upaya ini membutuhkan pengetahuan terkait tata guna lahan sepanjang rute BSD Link dan fluktuasi volume penumpang BSD Link di setiap halte. Survei terkait hal tersebut telah dilakukan pada Koridor Sektor 1.3-Greenwich Park pada jam puncak pagi. Hasil survei menunjukkan bahwa bangkitan perjalanan terbesar berasal dari halte East Bussiness District (50\%), tarikan perjalanan terbesar berasal dari halte The Breeze (45\%) untuk arah Sektor 1.3 - Greenwich Park. Bangkitan perjalanan terbesar berasal dari halte Naava Park (55\%) dan tarikan perjalanan terbesar berasal dari halte Sektor 1.3 (35\%) untuk arah Greenwich Park - Sektor 1.3.
\end{abstract}

Kata kunci: Tata guna lahan, bangkitan perjalanan, tarikan perjalanan, BSD Link, Sektor 1.3 - Greenwich Park

\begin{abstract}
Bumi Serpong Damai (BSD) is one of self contained city in Jabodetabek district. Sinarmas as developer of BSD started to develop Mass Rapid Transit which special operated on that. Concept of MRT has been operated in the form of Bus Rapid Transit. Amount of bus shelter for one corridor with two lines not exactly equal, because route for departure and return are different. That was caused by differences characteristic of land use. Thus, interaction between land use with fluctuation of passengers volume need to known. This attempt needs knowledge on land use along the route and fluctuation of passengers volume in each bus shelter. Survey on that knowledge were executed on Corridor Sector 1.3 - Greenwich Park during morning peak hour. The result indicates that peak of trip production generated by East Bussines Distcrict (50\%) shelter, peak of trip attraction generated by The Breeze (45\%) shelter for Sector 1.3 - Greenwich Park line. Peak of trip production generated by Naava Park $(55 \%)$ shelter and peak of trip attraction generated by Sektor $1.3(35 \%)$ shelter for Greenwich Park - Sector 1.3 line.
\end{abstract}

Keywords: Land use, trip production, trip attraction, BSD Link, Sector 1.3 - Greenwich Park 


\section{Latar Belakang}

Angkutan Umum Massal merupakan salah satu kebutuhan di beberapa negara, khususnya kawasan perkotaan dengan mobilitas masyarakat yang tinggi. Indonesia telah mengembangkan Angkutan Umum Massal berupa Commuter Line (KRL), Mass Rapid Transit (MRT), Light Rapid Transit (LRT), serta Bus Rapid Transit (BRT) di beberapa kota besar, salah satunya di kawasan Jabodetabek. BSD City merupakan salah satu kota satelit di kawasan Jabodetabek yang pengembangannya diarahkan untuk dapat menjadi kota mandiri. Pengembangan yang dilakukan mencakup beberapa sektor kehidupan antara lain ekonomi, sosial, politik, budaya, serta transportasi. Untuk sektor transportasi, upaya pengembangan berupa pengoperasian angkutan umum yang bersifat massal di kawasan BSD City, dengan tujuan untuk mengurangi kemacetan, menjaga kualitas lingkungan, serta terjangkau oleh semua lapisan masyarakat. (Leng et al., 2012). Angkutan umum massal yang beroperasi di kawasan BSD City antara lain KRL, Trans Jakarta, angkutan kota, serta BSD Link. BSD Link memiliki 4 rencana koridor yang akan dioperasikan, dari 4 rencana koridor tersebut hanya 3 koridor yang telah dioperasikan, yaitu The Breeze - Aeon Mall - ICE BSD - The Breeze, Sektor 1.3 - Greenwich Park, dan The Avani - Sektor 1.3. Untuk pengembangan koridor baru terutama 1 koridor yang belum dioperasikan maka dibutuhkan kajian terkait interaksi pola tata guna lahan dengan fluktuasi volume penumpang di setiap halte pada koridor yang telah beroperasi. (Steijin, 2014)

Pola tata guna lahan/land use di setiap halte merupakan parameter yang penting untuk dipertimbangkan karena berkaitan dengan tingkat aksesibilitas masyarakat, nilai bangkitan dan tarikan perjalanan di kawasan tersebut. (Nugroho, 2013). Lokasi halte angkutan umum di suatu tata guna lahan yang padat dengan perkantoran, pertokoan, jasa, perumahan, pendidikan, rumah sakit pada suatu kawasan CBD, Kota, dan Pinggiran akan berpengaruh terhadap volume penumpang di setiap halte tersebut. (Indah, 2013). Oleh sebab itu, rute keberangkatan dan kembali tidak persis sama sehingga akan berpengaruh pada jumlah halte dalam satu koridor bus untuk kedua arah. (Cervero, Murakami and Miller M, 2009)

Untuk mengetahui interaksi antara tata guna lahan/land use dengan fluktuasi volume penumpang di setiap halte pada satu koridor bus, maka ada beberapa pertanyaan dasar yang timbul antara lain bagaimana bentuk/pola tata guna lahan di sepanjang koridor bus BSD Link khususnya Sektor 1.3 - Greenwich Park. Bagaimana bentuk distribusi naik dan turun penumpang di setiap halte BSD Link koridor Sektor 1.3 - Greenwich Park. Halte mana saja pada BSD Link koridor Sektor 1.3 - Greenwich Park yang menghasilkan bangkitan dan tarikan perjalanan terbesar. (Ananda Upa and Suprayitno, 2016b). Penelitian ini nantinya akan menunjukkan hasil identifikasi tata guna lahan, perhitungan volume penumpang dan pemetaan bangkitan serta tarikan perjalanan di setiap halte bus BSD Link koridor Sektor 1.3 - Greenwich Park, yang diperlukan untuk mengkaji bentuk interaksi pola tata guna lahan/land use dan fluktuasi volume penumpang.

\section{Metode Penelitian}

Tata guna lahan/land use merupakan pengaturan mengenai penggunaan lahan di mana memerlukan sumber daya manusia dan sumber daya lainnya. (Susanti, Soemitro and Suprayitno, 2017). Ada beberapa jenis penggunaan lahan yaitu lahan kota terbagi menjadi lahan terbangun dan lahan tak terbangun. Lahan terbangun 
terdiri dari perumahan, industri, perdagangan, jasa dan perkantoran. Lahan tak terbangun terbagi menjadi lahan tak terbangun yang digunakan untuk aktivitas kota (kuburan, rekreasi, transportasi, ruang terbuka) dan lahan tak terbangun non aktivitas kota (pertanian, perkebunan, area perairan, produksi, dan penambangan sumber daya alam). Penggunaan lahan di suatu wilayah, perlu diketahui komponenkomponen penggunaan lahannya (Pemerintah Republik Indonesia, 2007). Klasifikasi tata guna lahan dibedakan berdasarkan lokasi dan jarak tempat henti yang ditunjukkan pada Tabel 1. (Direktur Jenderal Perhubungan Darat., 1996)

Tabel 1 Klasifikasi tata guna lahan

\begin{tabular}{llcc}
\hline No & \multicolumn{1}{c}{ Tata Guna Lahan } & Lokasi & $\begin{array}{c}\text { Jarak Tempat } \\
\text { Henti }(\mathrm{m})\end{array}$ \\
\hline 1. & Pusat kegiatan sangat padat: pasar dan pertokoan & CBD dan Kota & $200-300$ \\
\hline 2. & Padat: perkantoran, sekolahan, dan jasa & Kota & $300-400$ \\
\hline 3. & Pemukiman & Kota & $300-400$ \\
\hline 4. & Campuran padat: perumahan, sekolah, dan jasa & Pinggiran & $300-500$ \\
\hline 5. & $\begin{array}{l}\text { Campuran jarang: perumahan, ladang/sawah, } \\
\text { tanah kosong }\end{array}$ & Pinggiran & $500-1000$ \\
\hline
\end{tabular}

Bangkitan dan tarikan perjalanan bergantung pada dua aspek land use yaitu jenis land use dan jumlah aktivitas serta intensitas pada land use tersebut. (Aprilia, 2013) Jenis land use yang berbeda (pemukiman, pendidikan, dan komersil) mempunyai ciri bangkitan lalu lintas yang berbeda pula, antara lain jumlah arus lalu lintas, jenis lalu lintas (pejalan kaki, truk dan mobil) dan lalu lintas pada waktu tertentu (kantor yang menghasilkan lalu lintas pada pagi dan sore hari, pertokoan menghasilkan arus lalu lintas sepanjang hari) (Ofyar, 2000). Tarikan perjalanan merupakan jumlah pergerakan yang tertarik ke suatu land use atau zona tarikan pergerakan. (Kevin, Zala and Umigrar, 2011). Pergerakan lalu lintas merupakan fungsi land use yang menghasilkan arus lalu lintas. (Suprayitno and Upa, 2017). Hasil dari perhitungan tarikan lalu lintas berupa jumlah kendaraan, orang, atau barang per satuan waktu. (Ortuzar and Willumsen, 1994).

Verdy dan Hitapriya (2016) melakukan kajian terkait Analisis Hubungan Antara Jumlah Naik dan Turun Penumpang dengan Tata Guna Lahan (Studi kasus: Koridor 2 Trans Mamminasata). Penelitian ini menitikberatkan pada analisis bangkitan dan tarikan perjalanan serta cakupan wilayah (influence area) setiap halte pada koridor 2 Trans Mamminasata. Hasil penelitian menunjukkan bahwa land use berupa campuran padat berupa perumahan dan jasa yang berlokasi di pinggiran memiliki bangkitan perjalanan terbesar, sedangkan land use pusat kegiatan padat (CBD) berupa sekolah, pasar, dan perkantoran yang berlokasi di kota memiliki tarikan perjalanan terbesar. Selain itu, cakupan wilayah (influence area) halte keberangkatan dari titik asal penumpang berjarak 1-2 km (80\%), >2 km (20\%), sedangkan untuk halte pemberhentian ke titik tujuan penumpang berjarak $0,5-2 \mathrm{~km}$ (75\%), >2 km (25\%). (Ananda Upa and Suprayitno, 2016a)

Hal yang mendasar untuk mengkaji interaksi tata guna lahan dan fluktuasi volume penumpang pada penelitian ini adalah pemetaan tata guna lahan sepanjang koridor, distribusi penumpang di setiap halte dan segmen jalan, serta sinkronisasi hasil pemetaan tata guna lahan dengan distribusi penumpang untuk mengetahui halte yang menghasilkan bangkitan dan tarikan perjalanan terbesar. (Ananda Upa and Setyadi, 2020) 
Penelitian ini bermanfaat untuk pengembangan koridor baru maupun koridor yang belum dioperasikan. BSD Link koridor Sektor 1.3 - Greenwich Park digunakan sebagai sampel untuk mengkaji interaksi tata guna lahan dan fluktuasi volume penumpang karena koridor tersebut melewati beberapa jenis tata guna lahan serta memiliki tipe daerah pelayanan yang sama dengan koridor lainnya, yaitu menghubungkan kawasan residensial (perumahan) dengan kawasan komersial (CBD). BSD Link koridor Sektor 1.3 - Greenwich Park seperti pada Gambar 1.

Survei dilakukan pada jam puncak pagi di Bulan Juni 2019. Ada 2 jenis survei yang dilakukan yaitu survei kondisi tata guna lahan/land use di setiap halte sepanjang koridor BSD Link Sektor 1.3 - Greenwich Park untuk mendapatkan gambaran/pola tata guna lahan untuk setiap halte, dan survei distribusi penumpang di setiap halte. (Suprayitno, Hitapriya \& Ryansyah, 2018). Survei distribusi penumpang melibatkan sebanyak +20 penumpang untuk setiap arahnya. Dengan demikian, total sampel yang berhasil dikumpulkan sebanyak 49 penumpang. Adapun total sampel tersebut diperoleh dalam kurun waktu 2 hari. Data yang dikumpulkan pada survei distribusi penumpang berupa data naik dan turun penumpang setiap halte untuk setiap arahnya. (Ananda Upa, Suprayitno and Ryansyah, 2018). Sedangkan survei kondisi tata guna lahan dilakukan dengan melihat kondisi kawasan yang dilalui oleh koridor BSD Link Sektor 1.3 Greenwich Park, kemudian diklasifikasikan dengan menggunakan Tabel 1. Hasil yang diperoleh berupa peta tata guna lahan dan distribusi penumpang setiap halte serta segmen jalan sepanjang koridor BSD Link Sektor 1.3 - Greenwich Park.

Analisis utama yang dilakukan dalam penelitian ini antara lain distribusi volume penumpang berbasis halte maupun segmen jalan untuk setiap arah, serta penentuan dan pemetaan tata guna lahan/land use halte yang memiliki peran sebagai pembangkit dan penarik perjalanan. (Amijaya and Suprayitno, 2018). Analisis distribusi volume penumpang berbasis halte dilakukan dengan cara menghitung jumlah naik dan turun penumpang di setiap halte untuk setiap arahnya, sedangkan untuk analisis distribusi volume penumpang berbasis segmen jalan dilakukan dengan cara menghitung selisih antara jumlah penumpang yang naik dengan jumlah penumpang yang turun di setiap halte. (Susanti, Soemitro and Suprayitno, 2018). Sebagai ilustrasi perhitungan distribusi volume penumpang berbasis segmen jalan akan diberikan untuk segmen jalan 1 dan 2 .

Volume penumpang segmen jalan $1=3-0=3$

Volume penumpang segmen jalan $2=(3+2)-0=5$

Penentuan halte yang memiliki peran sebagai pembangkit perjalanan dilakukan dengan cara memilih lokasi halte yang digunakan oleh penumpang untuk berangkat (naik). Untuk menghitung persentase dari nilai bangkitan perjalanan pada halte dilakukan dengan cara membandingkan jumlah penumpang yang berangkat (naik) pada lokasi halte tersebut dengan total penumpang yang berangkat (naik) dari setiap halte dikali dengan $100 \%$. Sedangkan penentuan halte yang memiliki peran sebagai penarik perjalanan dilakukan dengan cara memilih lokasi halte yang digunakan oleh penumpang untuk turun. Untuk menghitung persentase dari nilai tarikan perjalanan pada halte dilakukan dengan cara membandingkan jumlah penumpang yang turun pada lokasi halte tersebut dengan total penumpang yang turun dari setiap halte dikali dengan $100 \%$. Sebagai ilustrasi perhitungan persentase bangkitan perjalanan akan diberikan untuk bangkitan perjalanan di halte East Bussiness District (arah Sektor 1.3 - Greenwich Park), sedangkan ilustrasi 
perhitungan persentase tarikan perjalanan akan diberikan untuk tarikan perjalanan di halte The Breeze (arah Sektor 1.3 - Greenwich Park).

Persentase bangkitan perjalanan (halte East Bussiness District) = $\frac{10}{20} \times 100 \%=50 \%$.

Persentase tarikan perjalanan (halte The Breeze) $=\frac{9}{20} \times 100 \%=45 \%$

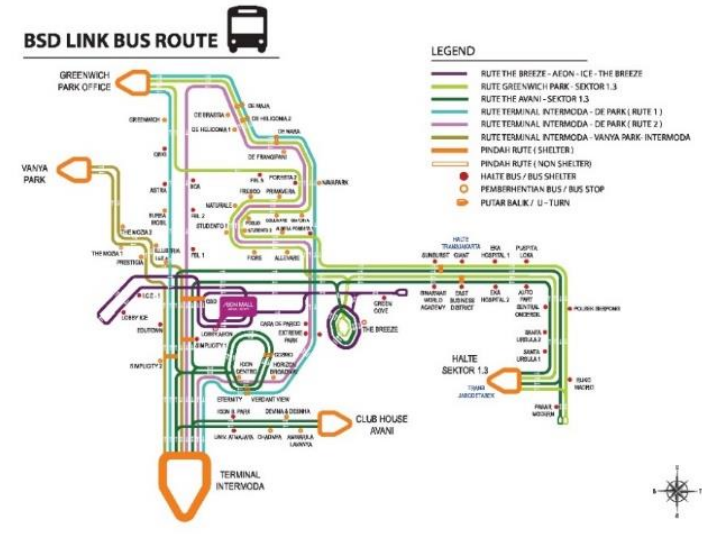

Gambar 1 BSD Link koridor sektor 1.3 - greenwich park

\section{Hasil dan Pembahasan}

Survei telah dilakukan dan data yang diperoleh dapat digunakan untuk kajian lebih lanjut sehingga dapat diketahui pola interaksi tata guna lahan dan fluktuasi volume penumpang. Poin utama yang diperoleh adalah peta tata guna lahan sepanjang koridor dan distribusi penumpang setiap halte serta segmen jalan sepanjang koridor BSD Link Sektor 1.3 - Greenwich Park. Berikut ini poin utama yang akan dipaparkan.

\subsection{Tata guna lahan/land use setiap halte}

Tata guna lahan/land use di sekitar halte yang merupakan tempat pemberhentian BSD Link penting untuk diketahui, karena berhubungan dengan bangkitan dan tarikan perjalanan.

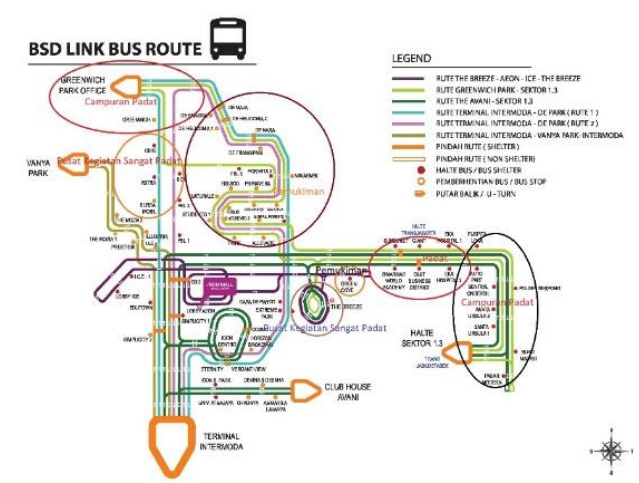

Gambar 2 Pemetaan land use BSD Link koridor sektor 1.3 - greenwich park

Berdasarkan hasil survei pemetaan yang telah dilakukan mengindikasikan bahwa pola tata guna lahan di sekitar halte BSD Link arah Sektor 1.3 - Greenwich Park yaitu $43 \%$ kawasan campuran padat, 22\% kawasan pusat kegiatan sangat padat, $21 \%$ kawasan padat, dan $14 \%$ kawasan pemukiman, sedangkan pola tata 
guna lahan di sekitar halte BSD Link arah Greenwich Park - Sektor 1.3 yaitu 58\% kawasan campuran padat, 25\% kawasan padat, dan $17 \%$ kawasan pemukiman. Hasil tersebut menunjukkan bahwa lokasi halte cukup strategis, sehingga hal tersebut dapat mendorong masyarakat menggunakan BSD Link untuk beraktivitas. Berikut ini hasil pemetaan tata guna lahan/land use sepanjang koridor Sektor 1.3 Greenwich Park ditunjukkan dalam Gambar 2.

Pada kenyataannya, pengoperasian BSD Link khususnya koridor Sektor 1.3 Greenwich Park di kawasan BSD City kurang diminati oleh masyarakat. Sebagian besar masyarakat lebih memilih menggunakan kendaraan pribadi dibandingkan BSD Link dalam aktivitas sehari-hari. Oleh sebab itu, pemetaan pola tata guna lahan di sekitar halte sangat penting untuk dilakukan, mengingat kedepannya perlu adanya evaluasi kembali terkait keberadaan/posisi halte BSD Link untuk pengembangan koridor baru atau pengoperasian koridor yang belum dioperasikan. Tujuannya adalah mendorong minat masyarakat khususnya di kawasan BSD City untuk menggunakan angkutan umum seperti BSD Link dalam beraktivitas seharihari. Hasil survei pemetaan pola tata guna lahan di sekitar halte BSD Link untuk arah Sektor 1.3 - Greenwich Park dan sebaliknya ditunjukkan pada Tabel 2 dan Tabel 3.

Tabel 2 Tata guna lahan sekitar halte BSD Link arah Sektor 1.3 - Greenwich Park

\begin{tabular}{cccc}
\hline No. & Nama halte & Tata guna lahan & Lokasi \\
\hline 1 & Sektor 1.3 & Campuran padat: perumahan, pertokoan, pasar & Pinggiran \\
\hline 2 & Santa Ursula 1 & Campuran padat: perumahan, pertokoan & Pinggiran \\
\hline 3 & Santa Ursula 2 & Campuran padat: perumahan, pertokoan & Pinggiran \\
\hline 4 & Santa Onderdil & Campuran padat: perumahan, pertokoan, jasa & Pinggiran \\
\hline 5 & Auto Part & Campuran padat: perumahan, pertokoan, jasa & Pinggiran \\
\hline 6 & Eka Hospital 2 & Padat: sekolah, rumah sakit, pertokoan & Kota \\
\hline 7 & East Business Distrct & Padat: perkantoran, pertokoan & Kota \\
\hline 8 & Sinar Mas World & Padat: sekolah, perkantoran & Kota \\
& Academy 1 & Pemukiman & Kota \\
\hline 9 & Green Cove & hiburan & CBD dan Kota \\
\hline 10 & The Breeze & Pusat kegiatan sangat padat: perkantoran, jasa & CBD dan Kota \\
\hline 11 & Simpang Foresta & Pusat kegiatan sangat padat: perkantoran, jasa \\
& hiburan & Kota \\
\hline 12 & Foresta Bussiness Loft & Pemukiman & CBD dan Kota \\
\hline 13 & Q Big & Pusat kegiatan sangat padat: perkantoran, jasa & Pinggiran \\
\hline 14 & Greenwich Park & Campuran padat: perumahan, pertokoan \\
\hline
\end{tabular}

Tabel 3 Tata guna lahan sekitar halte BSD Link arah Greenwich Park - Sektor 1.3

\begin{tabular}{cccc}
\hline No. & Nama halte & Tata guna lahan & Lokasi \\
\hline 1 & Greenwich Park & Campuran padat: perumahan, pertokoan & Pinggiran \\
\hline 2 & Foresta 1 & Pemukiman & Kota \\
\hline 3 & Naava Park 1 & Pemukiman & Kota \\
\hline 4 & SunBurst/Sinar Mas World & Kota \\
& Academy 2 & Padat: sekolah, perkantoran & Kota \\
\hline 5 & Giant & Padat: perkantoran, supermarket, jasa & Kota \\
\hline 6 & Eka Hospital 1 & Padat: sekolah, rumah sakit, pertokoan & Pinggiran \\
\hline 7 & Puspita Loka & Campuran padat: perumahan, pertokoan & Pinggiran \\
\hline 8 & Polsek Serpong & Campuran padat: pertokoan, jasa &
\end{tabular}




\begin{tabular}{cccc}
\hline 9 & Ruko Madrid & Campuran padat: pertokoan, jasa & Pinggiran \\
\hline 10 & Pasar Modern & Campuran padat: pertokoan, jasa, pasar & Pinggiran \\
\hline 11 & Griya Loka 1 & Campuran padat: perumahan, pertokoan, jasa & Pinggiran \\
\hline 12 & Sektor 1.3 & Campuran padat: perumahan, pertokoan, pasar & Pinggiran \\
\hline
\end{tabular}

\subsection{Distribusi volume penumpang setiap halte BSD Link koridor Sektor 1.3 - Greenwich Park}

Data naik dan turun penumpang yang telah diperoleh menyatakan karakteristik yang berkaitan dengan distribusi volume penumpang BSD Link. Titik keberangkatan BSD Link koridor Sektor 1.3 - Greenwich Park dan sebaliknya terletak pada halte yang lokasinya dekat dengan kawasan campuran padat: perumahan, pertokoan maupun pasar. Pada umumnya, lokasi halte yang merupakan titik keberangkatan BSD Link dekat dengan zona asal perjalanan. Di sisi lain, titik pemberhentian akan mendistribusikan penumpang ke zona tujuan, oleh sebab itu lokasi halte dekat dengan kawasan padat: sekolah, perkantoran, dan rumah sakit. Pada umumnya, lokasi halte yang merupakan titik pemberhentian BSD Link dekat dengan zona tujuan perjalanan. Hasil survei distribusi naik dan turun penumpang setiap halte sepanjang koridor BSD Link ditunjukkan dalam Tabel 4 dan Tabel 5.

Tabel 4 Data naik turun penumpang BSD Link arah Sektor 1.3 - Greenwich Park

\begin{tabular}{cccc}
\hline \multirow{2}{*}{ No. } & Halte BSD Link & \multicolumn{2}{c}{ Sektor 1.3- Greenwich Park } \\
\cline { 3 - 4 } & & Naik & Turun \\
\hline 1 & Sektor 1.3 & 3 & - \\
\hline 2 & Santa Ursula 1 & 2 & - \\
\hline 3 & Santa Ursula 2 & 3 & - \\
\hline 4 & Santa Onderdil & - & - \\
\hline 5 & Auto Part & - & - \\
\hline 6 & Eka Hospital 2 & - & - \\
\hline 7 & East Bussiness District & 10 & - \\
\hline 8 & Sinar Mas World Academy 1 & - & - \\
\hline 9 & Green Cove & - & 3 \\
\hline 10 & The Breeze & - & - \\
\hline 11 & Simpang Foresta & 2 & 5 \\
\hline 12 & Foresta Bussiness Loft 5 & - & 3 \\
\hline 13 & Q Big & - & - \\
\hline 14 & Greenwich Park & &
\end{tabular}

Berdasarkan Tabel 4 dapat diketahui bahwa bangkitan perjalanan dihasilkan oleh halte Sektor 1.3, Santa Ursula 1, Santa Ursula 2, East Bussiness District, serta Simpang Foresta sedangkan tarikan perjalanan dihasilkan oleh halte The Breeze, Simpang Foresta, Q Big, dan Greenwich Park untuk arah Sektor 1.3 - Greenwich Park.

Tabel 5 Data naik turun penumpang BSD Link arah Greenwich Park - Sektor 1.3

\begin{tabular}{|c|c|c|c|}
\hline \multirow{2}{*}{ No. } & \multirow{2}{*}{ Halte BSD Link } & \multicolumn{2}{|c|}{ Greenwich Park - Sektor 1.3} \\
\hline & & Naik & Turun \\
\hline 1 & Greenwich Park & 5 & - \\
\hline 2 & Foresta 1 & 2 & - \\
\hline 3 & Naava Park 1 & 16 & - \\
\hline 4 & $\begin{array}{c}\text { SunBurst/Sinar Mas } \\
\text { World Academy } 2\end{array}$ & - & 3 \\
\hline
\end{tabular}




\begin{tabular}{cccc}
\hline 5 & Giant BSD & 2 & 3 \\
\hline 6 & Eka Hospital 1 & -1 & - \\
\hline 7 & Puspita Loka & 2 & - \\
\hline 8 & Polsek Serpong & - & - \\
\hline 9 & Ruko Madrid & - & 7 \\
\hline 10 & Pasar Modern & - & 2 \\
\hline 11 & Griya Loka 1 & - & 2 \\
\hline 12 & Sektor 1.3 & - & 10 \\
\hline
\end{tabular}

Berdasarkan Tabel 5. dapat diketahui bahwa bangkitan perjalanan dihasilkan oleh halte Greenwich Park, Foresta 1, Nava Park 1, Giant BSD, Eka Hospital, dan Puspita Loka, sedangkan tarikan perjalanan dihasilkan oleh halte SunBurst/Sinar Mas World Academy 2, Giant BSD, Ruko Madrid, Pasar Modern, Griya Loka 1, dan Sektor 1.3 untuk arah Greenwich Park - Sektor 1.3.

\subsection{Distribusi volume penumpang setiap segmen jalan sepanjang koridor BSD Link Sektor 1.3 - Greenwich Park}

Distribusi penumpang BSD Link pada segmen jalan sepanjang koridor Sektor 1.3 - Greenwich Park juga perlu untuk diketahui. Karena data tersebut dapat memberikan penegasan terhadap hasil pemetaan tata guna lahan dan volume penumpang di setiap halte.

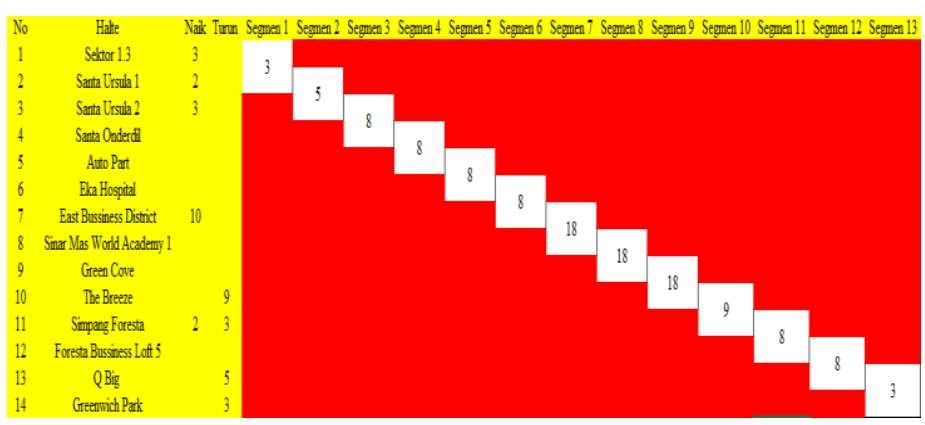

Gambar 3 Analisis distribusi volume penumpang BSD Link pada segmen jalan koridor sektor 1.3 - greenwich Park

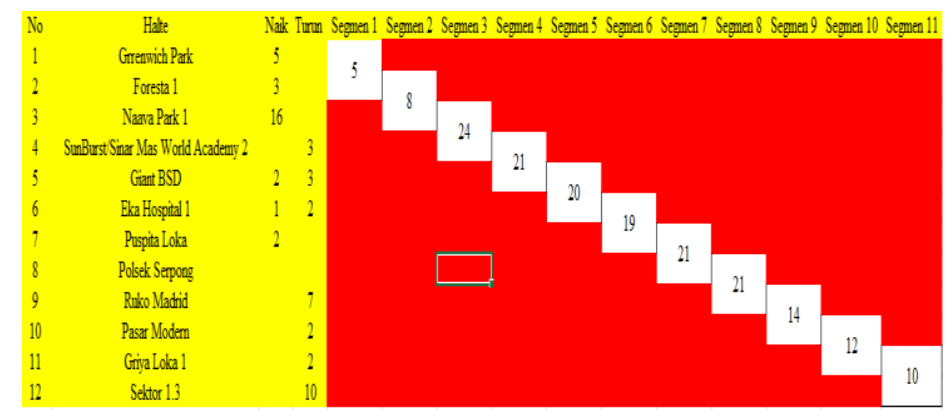

Gambar 4 Analisis distribusi volume penumpang BSD Link pada segmen jalan koridor greenwich park - sector 1.3

Analisis distribusi penumpang BSD Link pada segmen jalan didasarkan pada jumlah sampel yang diperoleh yaitu \pm 20 orang untuk setiap arah. Distribusi penumpang BSD Link pada segmen jalan sepanjang koridor Sektor 1.3-Greenwich 
Park memiliki kesamaan untuk kedua arahnya. Jumlah penumpang terbanyak berada pada bagian tengah segmen jalannya. Jumlah penumpang paling banyak terlihat antara halte East Bussiness District-Green Cove untuk arah pertama (Sektor 1.3 - Greenwich Park) dan antara halte Eka Hospital 1 - Ruko Madrid untuk arah yang kedua (Greenwich Park - Sektor 1.3). Halte-halte tersebut terletak pada kawasan padat (bisnis) di BSD City. Analisis dan bentuk distribusi volume penumpang BSD Link pada segmen jalan sepanjang koridor Sektor 1.3 Greenwich Park ditunjukkan dalam Gambar 3, 4, 5, dan Gambar 6.

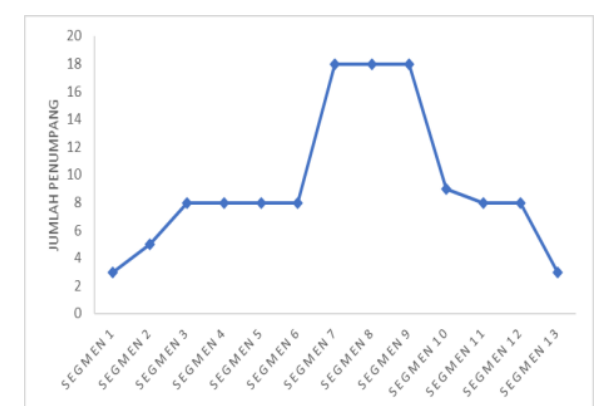

Gambar 5 Distribusi volume penumpang BSD Link setiap segmen jalan sepanjang koridor sektor 1.3 - greenwich Park

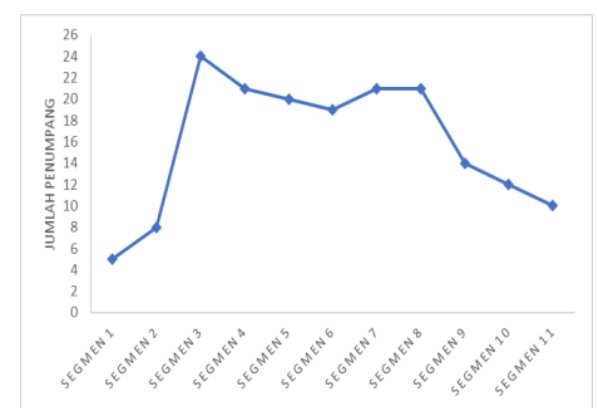

Gambar 6 Distribusi volume penumpang BSD Link setiap segmen jalan sepanjang koridor greenwich park - sektor 1.3

\subsection{Kajian pola interaksi tata guna lahan/land use dan volume penumpang BSD Link Sektor 1.3 - Greenwich Park}

Interaksi yang terjalin antara tata guna lahan/land use sekitar halte dengan volume penumpang di setiap haltenya penting untuk diketahui agar diperoleh hasil terkait halte dan jenis tata guna lahan/land use yang memiliki bangkitan perjalanan terbesar serta halte dan jenis tata guna lahan/land use yang memiliki tarikan perjalanan terbesar. Berdasarkan analisis yang telah dilakukan maka diperoleh bangkitan perjalanan terbesar dihasilkan oleh halte East Bussiness District (50\%) dengan jenis tata guna lahan/land use berupa kawasan padat, sedangkan tarikan perjalanan terbesar dihasilkan oleh halte halte The Breeze $(45 \%)$ dengan jenis tata guna lahan/land use berupa kawasan pusat kegiatan sangat padat, akan tetapi secara umum, halte yang berada pada tata guna lahan/land use campuran padat hingga padat menghasilkan bangkitan perjalanan sedangkan halte yang berada pada tata guna lahan/land use padat hingga pusat kegiatan sangat padat menghasilkan tarikan perjalanan untuk arah Sektor 1.3 - Greenwich Park. 
Selain itu, diperoleh pula bangkitan perjalanan terbesar dihasilkan oleh halte Naava Park 1 (55\%) dengan jenis tata guna lahan/land use berupa kawasan pemukiman sedangkan tarikan perjalanan terbesar dihasilkan oleh Sektor $1.3(35 \%)$ dengan jenis tata guna lahan berupa kawasan campuran padat. Akan tetapi secara umum, halte yang berada pada tata guna lahan/land use pemukiman hingga campuran padat menghasilkan bangkitan perjalanan, sedangkan halte yang berada pada tata guna lahan/land use campuran padat hingga padat menghasilkan tarikan perjalanan untuk arah Greenwich Park - Sektor 1.3. Dari hasil tersebut dapat diketahui bahwa pola interaksi antara tata guna lahan/land use dengan volume penumpang adalah halte yang berada pada tata guna lahan/land use berupa kawasan pemukiman hingga campuran padat pada umumnya memiliki jumlah penumpang yang berangkat (naik) banyak (bangkitan perjalanan terbesar), sedangkan halte yang berada pada tata guna lahan/land use berupa kawasan padat hingga pusat kegiatan sangat padat pada umumnya memiliki jumlah penumpang yang turun banyak (tarikan perjalanan terbesar). Hasil analisis pola interaksi tata guna lahan/land use dengan volume penumpang BSD Link Sektor 1.3 - Greenwich Park ditunjukkan dalam Tabel 6.

Tabel 6 Pola interaksi tata guna lahan/land use dan volume penumpang BSD Link Sektor 1.3 - Greenwich Park

\begin{tabular}{|c|c|c|c|c|c|}
\hline Koridor & Nama halte & Jumlah & $\%$ & Keterangan & Lokasi \\
\hline \multirow{9}{*}{$\begin{array}{l}\text { Sektor } 1.3- \\
\text { Greenwich } \\
\text { Park }\end{array}$} & Sektor 1.3 & 3 & 15 & \multirow{5}{*}{ Halte naik } & \multirow{5}{*}{$\begin{array}{l}\text { Land use berupa } \\
\text { campuran padat hingga } \\
\text { padat menghasilkan } \\
\text { bangkitan perjalanan }\end{array}$} \\
\hline & Santa Ursula 1 & 2 & 10 & & \\
\hline & Santa Ursula 2 & 3 & 15 & & \\
\hline & East Bussiness District & 10 & 50 & & \\
\hline & Simpang Foresta & 2 & 10 & & \\
\hline & The Breeze & 9 & 45 & \multirow{4}{*}{ Halte turun } & \multirow{4}{*}{$\begin{array}{l}\text { Land use berupa padat } \\
\text { hingga pusat kegiatan } \\
\text { sangat padat menghasilkan } \\
\text { tarikan perjalanan }\end{array}$} \\
\hline & Simpang Foresta & 3 & 15 & & \\
\hline & Q Big & 5 & 25 & & \\
\hline & Greenwich Park & 3 & 15 & & \\
\hline \multirow{13}{*}{$\begin{array}{l}\text { Greenwich } \\
\text { Park - } \\
\text { Sektor } 1.3\end{array}$} & Greenwich Park & 5 & 17 & \multirow{5}{*}{ Halte naik } & \multirow{5}{*}{$\begin{array}{c}\text { Land use berupa } \\
\text { pemukiman hingga } \\
\text { campuran padat memiliki } \\
\text { bangkitan perjalanan } \\
\text { tinggi }\end{array}$} \\
\hline & Foresta 1 & 3 & 10 & & \\
\hline & Naava Park 1 & 16 & 55 & & \\
\hline & Giant BSD & 2 & 7 & & \\
\hline & Eka Hospital 1 & 1 & 4 & & \\
\hline & Puspita Loka & 2 & 7 & \multirow{8}{*}{ Halte turun } & \multirow{8}{*}{$\begin{array}{l}\text { Land use berupa } \\
\text { campuran padat hingga } \\
\text { padat memiliki tarikan } \\
\text { perjalanan yang tinggi }\end{array}$} \\
\hline & SWA 2 & 3 & 10 & & \\
\hline & Giant BSD & 3 & 10 & & \\
\hline & Eka Hospital 1 & 2 & 7 & & \\
\hline & Ruko Madrid & 7 & 24 & & \\
\hline & Pasar Modern & 2 & 7 & & \\
\hline & Griya Loka 1 & 2 & 7 & & \\
\hline & Sektor 1.3 & 10 & 35 & & \\
\hline
\end{tabular}

\section{Kesimpulan dan Saran}

\subsection{Kesimpulan}

Tujuan dari penelitian ini telah tercapai. Adapun beberapa poin utama yang dapat disimpulkan fokus terhadap pola interaksi tata guna lahan/land use dan volume penumpang BSD Link Sektor 1.3- Greenwich Park antara lain Pola tata guna lahan sekitar halte BSD Link arah Sektor 1.3- Greenwich Park berupa 43\% kawasan campuran padat, 22\% kawasan pusat kegiatan sangat padat, $21 \%$ kawasan 
padat, dan $14 \%$ kawasan pemukiman, sedangkan pola tata guna lahan sekitar halte BSD Link arah Greenwich Park - Sektor 1.3 berupa 58\% kawasan campuran padat, $25 \%$ kawasan padat, dan $17 \%$ kawasan pemukiman. Titik keberangkatan BSD Link Sektor 1.3- Greenwich Park dan sebaliknya terletak pada halte yang lokasinya dekat dengan kawasan campuran padat: perumahan, pertokoan maupun pasar. Di sisi lain, titik pemberhentian akan mendistribusikan penumpang ke zona tujuan, oleh sebab itu lokasi halte dekat dengan kawasan padat: sekolah, perkantoran, dan rumah sakit. Jumlah penumpang paling banyak terlihat antara halte East Bussiness District - Green Cove untuk arah pertama (Sektor 1.3 - Greenwich Park) dan antara halte Eka Hospital 1 - Ruko Madrid untuk arah yang kedua (Greenwich Park Sektor 1.3). Halte-halte tersebut terletak pada kawasan padat (bisnis) di BSD City.

Bangkitan perjalanan terbesar dihasilkan oleh halte East Bussiness District (50\%) dengan jenis tata guna lahan/land use berupa kawasan padat, sedangkan tarikan perjalanan terbesar dihasilkan oleh halte The Breeze (45\%) dengan jenis tata guna lahan/land use berupa kawasan pusat kegiatan sangat padat. Akan tetapi secara umum, halte yang berada pada tata guna lahan/land use campuran padat hingga padat menghasilkan bangkitan perjalanan, sedangkan halte yang berada pada tata guna lahan/land use padat hingga pusat kegiatan sangat padat menghasilkan tarikan perjalanan untuk arah Sektor 1.3 - Greenwich Park. Bangkitan perjalanan terbesar dihasilkan oleh halte Naava Park 1 (55\%) dengan jenis tata guna lahan/land use berupa kawasan pemukiman sedangkan tarikan perjalanan terbesar dihasilkan oleh halte Sektor 1.3 (35\%) dengan jenis tata guna berupa kawasan campuran padat. Akan tetapi secara umum, halte yang berada pada tata guna lahan/land use pemukiman hingga campuran padat menghasilkan bangkitan perjalanan, sedangkan halte yang berada pada tata guna lahan/land use campuran padat hingga padat menghasilkan tarikan perjalanan untuk arah Greenwich Park - Sektor 1.3.

\subsection{Saran}

Saran yang dapat diberikan untuk penelitian lebih lanjut adalah penambahan jumlah penumpang yang dijadikan sebagai sampel penelitian sehingga dapat diperoleh hasil yang lebih akurat dan sinkron antara pemetaan tata guna lahan dan distribusi penumpang setiap halte untuk menentukan halte yang memiliki bangkitan dan tarikan perjalanan yang terbesar.

\section{Daftar Kepustakaan}

Amijaya, J. and Suprayitno, H, 2018. Permodelan Bangkitan Dan Tarikan Perjalanan Moda Sepeda Motor Di Wilayah Perkotaan Gresik Tahun 2018. Jurnal Manajemen Aset Infrastruktur \& Fasilitas, 2(0), pp. 1-10. doi: 10.12962/j26151847.v2i0.4819.

Ananda Upa, V. and Setyadi, R, 2020. Analisis Karakteristik Pengguna BSD Link Untuk Desain Koridor Baru Menggunakan Model Permintaan Perjalanan. Jurnal Politeknologi.

Ananda Upa, V. and Suprayitno, H, 2016a. Analisis Hubungan Antara Jumlah Naik dan Turun Penumpang dengan Tata Guna Lahan (Studi Kasus: Koridor 2 Trans Mamminasata). Jurnal Ilmiah Gema Aktualita. 
Ananda Upa, V. and Suprayitno, H, 2016b. Mamminasata BRT User Trip Characteristic for Design of Demand Modelling Method for a New BRT Lines. IPTEKS The Journal of Technology and Sciences.

Ananda Upa, V., Suprayitno, H. and Ryansyah, M, 2018. Perbandingan dan Sintesis Karakteristik Perilaku Perjalanan Pengguna Bis Trans Mamminasata dan Bis Trans Koetaradja. Jurnal Manejemen Aset Infrastruktur \& Fasilitas, 2(2), pp. 69-82. doi: 10.12962/j26151847.v2i2.4341.

Aprilia, D, 2013. Evaluasi Kesesuaian Lokasi Terminal Kertosono di Kabupaten Kertosono. Universitas Negeri Surabaya.

Cervero, R., Murakami, J. and Miller M, 2009. Direct Ridership Model of Bus Rapid Transit in Los Angeles Country.

Direktur Jenderal Perhubungan Darat, 1996. Keputusan Nomor 271/HK.105/DRJD/96 tentang Pedoman Teknis Perekayasaan Tempat Perhentian Kendaraan Penumpang Umum.

Indah, R, 2013. Identifikasi Lokasi dan Fungsi Halte Sebagai Tempat Henti Angkutan Umum Berdasarkan Tata Guna Lahan di Kota Bogor. Universitas Pakuan Bogor.

Kevin, B., Zala, L. . and Umigrar, F, 2011. Transportation Planning Models: A Review Recent Trends in Engineering and Technology.

Leng, Y. et al, 2012. Evaluation on Transfer Efficiency at Integrated Transport Terminals Trough Multilevel Grey Evaluation. Procedia Social and Behavioral Sciences.

Nugroho, C, 2013. Aksesibilitas Halte dan Kualitas Pelayanan Trans Jogja dengan Keputusan Pengguna. Universitas Negeri Yogyakarta.

Ofyar, Z. T, 2000. Perencanaan dan Pemodelan Transportasi. Institut Teknologi Bandung, Bandung

Ortuzar, J. D. and Willumsen, L. G, 1994. Modelling Transport. John Wiley \& Sons, New York

Pemerintah Republik Indonesia, 2007. Undang-Undang Nomor 26 Tahun 2007 tentang Penataan Ruang.

Steijin, J. V, 2014. Creating Feeder Bus Lines for Trans Jakarta BRT. University of Twente.

Suprayitno, Hitapriya \& Ryansyah, M, 2018. Karakteristik Pelaku dan Perilaku Perjalanan Penumpang Bus Trans Koetaradja. Jurnal Aplikasi Teknik Sipil, 16(2), pp. 55-62.

Suprayitno, H. and Upa, V. A, 2017. Special Conventional Transport Model for a New BRT Line Passenger Demand Prediction (The General Modeling Method). Journal of Technology and Social Science, 1(3), pp. 10-18.

Susanti, A., Soemitro, R. A. . and Suprayitno, H, 2017. Identifikasi Awal Kondisi Land Use di Tiap-Tiap Stasiun yang Menjadi Tempat Pemberhentian KA Penumpang di Kota Surabaya. Rekayasa Teknik Sipil.

Susanti, A., Soemitro, R. A. A. and Suprayitno, H, 2018. Analisis Perbedaan Volume Naik Turun Penumpang di Tiap-Tiap Stasiun Pemberhentian KA Komuter Surabaya - Sidoarjo (SUSI). Rekayasa Teknik Sipil. 